\title{
Complete genome sequence of Ornithobacterium rhinotracheale strain ORT-UMN 88
}

\author{
Emilie S Zehr $^{1 *}$, Darrell O Bayles ${ }^{2}$, William D Boatwright ${ }^{1}$, Louisa B Tabatabai ${ }^{1,3}$ and Karen B Register ${ }^{1}$
}

\begin{abstract}
Ornithobacterium rhinotracheale strain ORT-UMN 88 is a Gram-negative, pleomorphic, rod-shaped bacterium and an etiologic agent of pneumonia and airsacculitis in poultry. It is a member of the family Flavobacteriaceae of the phylum Bacteroidetes. O. rhinotracheale strain ORT-UMN 88 was isolated from the pneumonic lung of a turkey in 1995. It was the isolate first used to experimentally reproduce disease in turkeys and has since been the focus of investigations characterizing potential virulence factors of the bacterium. The genome of $O$. rhinotracheale strain ORT-UMN 88 consists of a circular chromosome of 2,397,867 bp with a total of 2300 protein-coding genes, nine RNA genes, and one noncoding RNA gene. A companion paper in this issue of SIGS reports the non-contiguous finished genome sequence of an additional strain of O. rhinotracheale, isolated in 2006.
\end{abstract}

Keywords: Ornithobacterium rhinotracheale, Poultry, Respiratory disease, Genome sequence

\section{Introduction}

Ornithobacterium rhinotracheale appears to have been the cause of respiratory disease in poultry since at least 1981 [1], although its biochemical characteristics and phylogenetic position were not determined until the early 1990's [2,3]. It is a global pathogen and has been isolated not only from turkeys and chickens but also a variety of other domesticated and wild birds, including chukar partridges, ducks, geese, guinea fowl, gulls, ostriches, partridges, pheasants, pigeons, quail, rooks, and falcons $[4,5]$. A typing scheme based on the reaction of monospecific antisera with heat-extracted antigens has so far discriminated 18 serotypes of $O$. rhinotracheale, designated as $\mathrm{A}$ through $\mathrm{R}[1,4]$, although not all isolates are typeable. The most common clinical signs of disease related to $O$. rhinotracheale are pneumonia, tracheitis, airsacculitis, sinusitis, and pericarditis $[1,4]$. These infections impose a substantial economic burden on the poultry industry worldwide, due to decreased egg production, reduced eggshell quality and hatchability, reduced weight gain, increased mortality, and increased condemnation rates [6-9]. Whole-cell bacterin and live, attenuated vaccines have met with limited success,

\footnotetext{
* Correspondence: emilie.zehr@ars.usda.gov

${ }^{1}$ Ruminant Diseases and Immunology Research Unit, U. S. Department of Agriculture, Agricultural Research Service, National Animal Disease Center, Ames, IA, USA

Full list of author information is available at the end of the article
}

likely due to the lack of cross-protection against heterologous serotypes. Recent studies have identified antigens that appear to provide cross-protective immunity when formulated as a recombinant, multi-component subunit vaccine [10].

O. rhinotracheale strain ORT-UMN 88 was isolated from the pneumonic lung of a turkey and classified as serotype A at the University of Minnesota, St. Paul, MN in 1995 [11]. This isolate was used as a challenge strain to reproduce the disease in previously healthy turkeys [12]. Further characterization revealed a dependence on iron for maximal growth, acquired through a mechanism apparently unrelated to siderophore production but possibly via an iron-bound protein pathway [13]. Although $O$. rhinotracheale has generally been considered nonhemolytic on blood agar, Tabatabai et al. [14] documented the $\beta$-hemolytic activity of numerous strains, including O. rhinotracheale strain ORT-UMN 88, and suggested that a hemolysin-like protein may function as a virulence factor. The availability of genome sequence data from $O$. rhinotracheale strains of known virulence will greatly facilitate efforts to define virulence factors and the molecular basis for pathogenesis. Here we present a description of the complete genome of $O$. rhinotracheale strain ORT-UMN 88 and its annotation. This isolate 
(alias P5887) was provided to the National Animal Disease Center by the University of Minnesota and is available upon request from the National Animal Disease Center Biological Agent Archive and Culture Collection.

\section{Organism information \\ Classification and features}

The genus Ornithobacterium belongs to the class "Flavobacteriia" and is in the family Flavobacteriaceae [15] (Table 1). O. rhinotracheale is the sole species within the genus. Phylogenetic analysis based on $16 \mathrm{~S}$ ribosomal RNA of O. rhinotracheale and other genera within the Flavobacteriaceae family is shown in Figure 1. The 16S rRNA sequences of $O$. rhinotracheale strain ORT-UMN 88 and the type strain, LMG 9086, share 99.9\% nucleotide sequence identity. Three rRNA loci were found in the O. rhinotracheale strain ORT-UMN 88 genome. All O. rhinotracheale strains in Figure 1 were isolated from turkeys, with the exception of strain LMG 11554, which was cultured from a rook.

O. rhinotracheale strain ORT-UMN 88 cells grown in broth medium are Gram-negative, pleomorphic rods, ranging from 1.53-1.86 $\mu \mathrm{m}$ (mean, $1.70 \mu \mathrm{m}$ ) in length compared to 0.59-0.72 $\mu \mathrm{m}$ (mean, 0.64 $\mu \mathrm{m}$ ) in width (Figure 2). The bacterium is nonmotile and microaerophilic, preferring $7.5 \% \mathrm{CO}_{2}$ humidified atmosphere from $30^{\circ} \mathrm{C}$ to $42^{\circ} \mathrm{C}$ for growth. Colonies are approximately $1 \mathrm{~mm}$ in diameter and yellowish in color after $48 \mathrm{~h}$ incubation at $37^{\circ} \mathrm{C}$ on blood agar. Unlike type strain LMG 9086 [3], O. rhinotracheale strain ORT-UMN 88 is $\beta$-hemolytic on $5 \%$ sheep blood agar [14].

Results of biochemical tests for O. rhinotracheale strains can be variable and strain-dependent [1]. After seven days of incubation at $37^{\circ} \mathrm{C}, O$. rhinotracheale strain ORT-UMN 88 is weakly acidic on a triple sugar iron agar slant and does not produce hydrogen sulfide or gas. Lactose and dextrose are weakly fermented and galactose, sucrose, sorbitol, xylose, and mannitol are not fermented, with or without the addition of $2 \%$ chicken serum. The isolate is lysine decarboxylase positive, ornithine decarboxylase negative, and urease positive.

\section{Genome sequencing information \\ Genome project history}

O. rhinotracheale strain ORT-UMN 88 was selected for sequencing on the basis of prior in vivo and in vitro characterization [12-14]. The Whole Genome Shotgun project and complete genome sequence of $O$. rhinotracheale strain ORT-UMN 88 has been deposited at DDBJ/ EMBL/GenBank under the accession no. CP006828. Sequencing, finishing, and final annotation were performed at the DNA Facility of Iowa State University and the National Animal Disease Center, Ames, IA. A summary of the project information is given in Table 2 .

\section{Growth conditions and genomic DNA preparation}

A clonal population of O. rhinotracheale strain ORTUMN 88, derived from three serial passages of a single colony, was archived at $-80^{\circ} \mathrm{C}$ for future analysis. The bacterium was grown on $5 \%$ sheep blood agar plates (Becton, Dickinson and Company, Sparks, MD) incubated for $48 \mathrm{~h}$ at $37^{\circ} \mathrm{C}$ with $7.5 \% \mathrm{CO}_{2}$ and $15 \%$ humidity. Colonies were used to inoculate $5 \mathrm{ml}$ of brain heart infusion broth in a snap-cap tube which was incubated at $37^{\circ} \mathrm{C}$ for $24 \mathrm{~h}$ with rotation at $100 \mathrm{rpm}$. Ten $\mathrm{ml}$ of these $24 \mathrm{~h}$ cultures were then diluted 10 -fold into fresh BHI broth. The newly inoculated culture was incubated in a $250-\mathrm{ml}$ flask at $37^{\circ} \mathrm{C}$ for $48 \mathrm{~h}$ at $75 \mathrm{rpm}$ (final $\mathrm{OD}_{600}=$ 0.371). An aliquot was plated on $5 \%$ sheep blood agar to confirm purity and $10 \mathrm{ml}$ was removed for DNA preparation. Cells were pelleted successively into one 2-ml microfuge tube at $16,000 \times \mathrm{g}$. Genomic DNA was isolated using the Wizard Genomic DNA Purification Kit (Promega Corporation, Madison, WI) with the following modifications: the cell pellet was resuspended in $480 \mu \mathrm{l}$ of $200 \mathrm{mM}$ EDTA, $60 \mu \mathrm{l}$ of $10 \mathrm{mg} / \mathrm{ml}$ lysozyme, and $60 \mu \mathrm{l}$ of double distilled water before lysis, then $10 \mu \mathrm{l}$ of $10 \mathrm{mg} / \mathrm{ml}$ RNase solution was added to the cell lysate. The precipitated genomic DNA was rehydrated at $65^{\circ} \mathrm{C}$ for $1 \mathrm{~h}$ in $10 \mathrm{mM}$ Tris- $\mathrm{HCl}, \mathrm{pH} 8.5$, evaluated on a $6 \%$ agarose gel to verify the lack of low molecular weight fragments, and quantified with Quant-iT PicoGreen dsDNA Assay Kit (Invitrogen, Carlsbad, CA).

\section{Genome sequencing and assembly}

A fully scaffolded genome was assembled using MIRA v. 3.4 [32] and the Roche gAssembler v. 2.6 to achieve $61 \times$ total genome coverage through the assembly of Roche GS FLX shotgun, GS FLX large insert $(7.9 \mathrm{~kb})$ mate pair, Illumina 75-bp single direction, and Illumina $2 \times 75$ bp paired-end sequencing reads. All remaining sequencing gaps in the scaffolded assembly were PCR amplified and sequenced by the Sanger method. GAP5 [33], from the Staden Package, was used as the editor for incorporating the gap-closing sequences, ultimately resulted in a completely closed genome. Base calling errors in the closed genome assembly were corrected by using SEQuel [34] to map Illumina reads back to the genome at approximately $100 \times$ total genome coverage.

\section{Genome annotation}

The assembled genome was submitted to the National Center for Biotechnology Information (Bethesda, MD) through the Whole Genome Shotgun genome sequencing portal [35] and genes were identified using the NCBI Prokaryotic Genome Annotation Pipeline. Signal peptides were identified with the SignalP 4.0 software [36], transmembrane helices were classified with the 
Table 1 Classification and general features of 0 . rhinotracheale strain ORT-UMN 88 in accordance with the MIGS recommendations [17]

\begin{tabular}{|c|c|c|c|}
\hline MIGS ID & Property & Term & Evidence code $^{a}$ \\
\hline & Current classification & Domain "Bacteria" & TAS [18,19] \\
\hline & & Phylum "Bacteroidetes" & TAS $[20,21]$ \\
\hline & & Class "Flavobacteriia" & TAS $[22,23]$ \\
\hline & & Order Flavobacteriales & TAS $[24,25]$ \\
\hline & & Family Flavobacteriaceae & TAS $[15,26,27]$ \\
\hline & & Genus Ornithobacterium & TAS $[28,29]$ \\
\hline & & Species rhinotracheale & TAS $[28,29]$ \\
\hline \multirow[t]{8}{*}{ MIGS-7 } & Subspecific genetic lineage (strain) & Strain ORT-UMN 88 & TAS [13] \\
\hline & & Serotype A & TAS [13] \\
\hline & Gram stain & Negative & $\operatorname{TAS}[1,4]$ \\
\hline & Cell shape & Pleomorphic rod & $\operatorname{TAS}[1,4]$ \\
\hline & Motility & Nonmotile & $\operatorname{TAS}[1,4]$ \\
\hline & Sporulation & Non-sporulating & $\operatorname{TAS}[1,4]$ \\
\hline & Temperature range & Mesophile $\left(30^{\circ} \mathrm{C}-42^{\circ} \mathrm{C}\right)$ & $\operatorname{TAS}[1,4]$ \\
\hline & Optimum temperature & $37^{\circ} \mathrm{C}$ & $\operatorname{TAS}[1,4]$ \\
\hline \multirow[t]{2}{*}{ MIGS-6.2 } & pH range; Optimum & 7.2-7.6 (BHI); 7.4 & TAS [1], IDA \\
\hline & Carbon source & Saccharolytic (glucose) & TAS [4] \\
\hline MIGS-6 & Habitat & Respiratory tract of birds worldwide & $\operatorname{TAS}[1,4]$ \\
\hline MIGS-6.3 & Salinity & Growth in BHI broth, (0.75\% salts) & TAS [1], IDA \\
\hline \multirow[t]{2}{*}{ MIGS-22 } & Oxygen requirement & Microaerophilic, anaerobic, or aerobic & TAS $[1,4]$ \\
\hline & Energy metabolism & Chemoorganotroph & TAS [4] \\
\hline MIGS-15 & Biotic relationship & Parasitic & TAS [4] \\
\hline MIGS-14 & Pathogenicity & Pneumonia, airsacculitis, tracheitis, pericarditis & TAS $[1,12]$ \\
\hline MIGS-16 & Specific host & Poultry & TAS $[1,4,12]$ \\
\hline \multirow[t]{2}{*}{ MIGS-18 } & Health status of host & Symptomatic & TAS $[12,13]$ \\
\hline & Biosafety level & $2 t$ & TAS [30] \\
\hline MIGS-19 & Trophic level & Chemoheterotroph & TAS [4] \\
\hline MIGS-23.1 & Isolation & Pneumonic turkey lung & TAS $[12,13]$ \\
\hline MIGS-4 & Geographic location & Minnesota, USA & TAS $[12,13]$ \\
\hline MIGS-5 & Time of sample collection & 1995 & TAS [12] \\
\hline MIGS-4.1 & Latitude & Not reported & \\
\hline MIGS-4.2 & Longitude & Not reported & \\
\hline MIGS-4.3 & Depth & Not reported & \\
\hline MIGS-4.4 & Altitude & Not reported & \\
\hline
\end{tabular}

${ }^{a}$ Evidence codes - IDA: Inferred from Direct Assay; TAS: Traceable Author Statement (i.e., a direct report exists in the literature); NAS: Non-traceable Author Statement (i.e., not directly observed for the living, isolated sample, but based on a generally accepted property for the species, or anecdotal evidence). Evidence codes are from the Gene Ontology project [31].

method of Krogh et al. [37], and the CRISPR motif was detected with a web tool described by Griss et al. [38].

\section{Genome properties}

The genome properties and statistics of $O$. rhinotracheale strain ORT-UMN 88 (Accession CP006828) are shown in Tables 3 and 4 and Figure 3. The complete genome consists of one circular 2,397,867 bp chromosome with a
$34.22 \% \mathrm{G}+\mathrm{C}$ content and no plasmids. Of the 2,389 genes predicted, 2,300 are protein-coding genes, 36 are pseudogenes, nine are RNA genes, and one is a noncoding RNA gene. The majority (59.61\%) of the proteincoding genes were assigned a putative function. The distribution of genes into COGs functional categories is presented in Table 4. Additionally, one CRISPR motif was detected. 


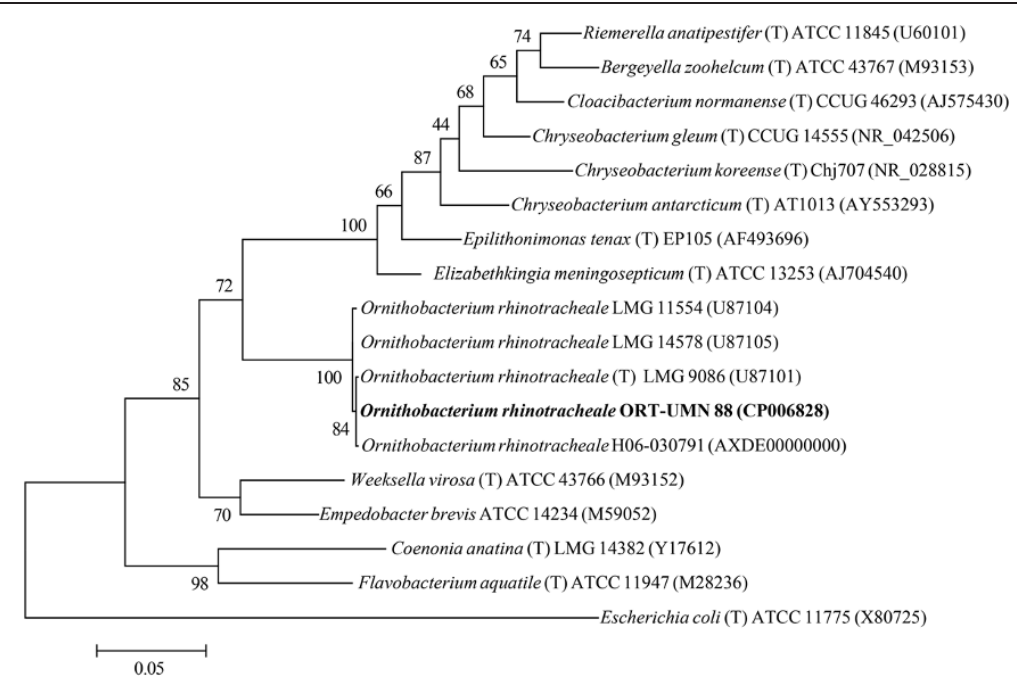

Figure 1 Phylogenetic tree based on 16S rRNA showing the position of $O$. rhinotracheale ORT-UMN 88 (highlighted in bold) in relation to other $O$. rhinotracheale isolates for which sequence is available and to the type strains $(\mathrm{T})$ of closely related species and genera within the family Flavobacteriaceae. Escherichia coli (a member of the Enterobacteriaceae family) was included as an outgroup. An internal region of the 165 rRNA (1251 bp with no gap-containing sites) was aligned using CLUSTALW, and phylogenetic inferences were obtained using the maximum likelihood method with the Jukes-Cantor model within MEGA version 5.10 software [16]. Numbers at the nodes are percentages of bootstrap values obtained by repeating the analysis 1000 times to generate a majority consensus tree. GenBank accession numbers for the sequences are given in parentheses. The scale bar represents $5 \%$ substitution per nucleotide position.

\section{Conclusions}

Other than the genome sequence of $O$. rhinotracheale strain ORT-UMN 88, reported here, genome sequences are available from only two additional isolates of the bacterium. The type strain, LMG 9086, was the first to be sequenced to completion. Those data were made publically available in GenBank in 2012, but a corresponding analysis has yet to be reported in the scientific literature. A non-contiguous finished genome sequence

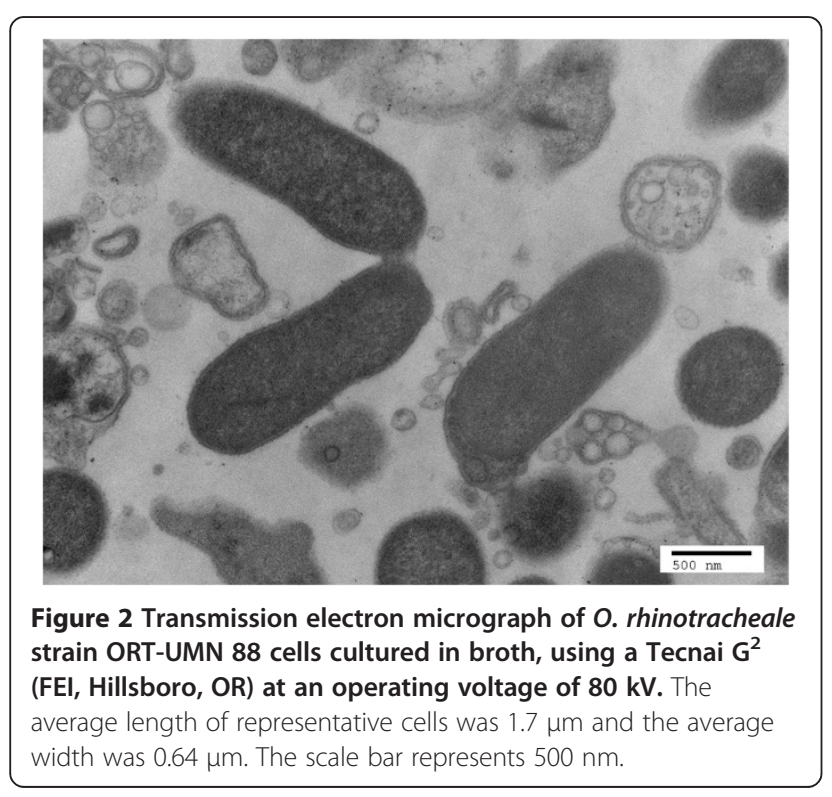

comprising seven contigs from strain H06-030791 is reported in a companion paper in this issue of SIGS [39].

Comparison of the aligned genomes of LMG 9086 and ORT-UMN 88 revealed that large rearrangements and inversions are the prominent distinguishing features. Relative to the type strain, the genome of ORT-UMN 88 contains a single inverted region of $\sim 18 \mathrm{~Kb}$ and two regions that are both inverted and rearranged, one of $\sim 354$ $\mathrm{Kb}$ and the other of $\sim 228 \mathrm{~Kb}$, each with a transposase or transposon found at one terminus. These same regions are similarly inverted and rearranged in the genome of strain H06-030791. However, H06-030791 has an additional rearrangement of $\sim 33 \mathrm{~Kb}$ and an inverted and translocated stretch of $\sim 59 \mathrm{~Kb}$, neither of which is similarly altered in ORT-UMN 88. Numerous smaller rearrangements can also be found in the sequence of ORT-UMN 88 relative to that of LMG 9086. As one example, in a region otherwise syntenous, homologs for 12/14 CDSs of ORT-UMN 88 (locus tags Q785_0029000360) are absent from this region of LMG 9086 and are instead located roughly $359 \mathrm{~Kb}$ distant. At the point of divergence in LMG 9086 is a CDS encoding a membraneassociated phosphatase for which no homolog is evident in ORT-UMN 88. Transposases border the regions of rearrangement in both isolates. Homologs for five of the 14 ORT-UMN 88 CDSs mentioned above are found at the same position in the ORT-UMN 88 and H06-030791 genomes. H06-030791 homologs of the remaining nine CDSs are split between two different regions, both distantly located, neither of which corresponds to the region 
Table 2 Project information of 0 . rhinotracheale strain ORT-UMN 88

\begin{tabular}{|c|c|c|}
\hline MIGS ID & Property & Term \\
\hline MIG-31 & Finishing quality & Finished \\
\hline MIGS-28 & Libraries used & $\begin{array}{l}\text { Three genomic libraries: two shotgun } \\
\text { libraries, one mate-pair ( } 8 \text { kb insert size) } \\
\text { library }\end{array}$ \\
\hline MIGS-29 & $\begin{array}{l}\text { Sequencing } \\
\text { platforms }\end{array}$ & $\begin{array}{l}\text { Illumina GA II, Roche GS FLX Titanium, } \\
\text { Sanger }\end{array}$ \\
\hline MIGS-31.2 & Fold coverage & $\begin{array}{l}\text { 61x (36x Roche FLX, 26x Illumina); } \\
\text { final SEQuel error correction with 100x } \\
\text { Illumina }\end{array}$ \\
\hline MIGS-30 & Assemblers & MIRA v3.4.0, Roche gsAssembler v2.8 \\
\hline \multirow[t]{6}{*}{ MIGS-32 } & $\begin{array}{l}\text { Gene calling } \\
\text { method }\end{array}$ & GeneMarkS + (NCBI PGAP) \\
\hline & GenBank ID & CP006828 \\
\hline & $\begin{array}{l}\text { GenBank Date } \\
\text { of Release }\end{array}$ & September 22, 2014 \\
\hline & GOLD ID & Gi0071044 \\
\hline & NCBI project ID & 219465 \\
\hline & Project relevance & Poultry respiratory pathogen \\
\hline MIGS-13 & $\begin{array}{l}\text { Source material } \\
\text { identifier }\end{array}$ & ORT-UMN 88 \\
\hline
\end{tabular}

in which they are found in LMG 9086. The LMG 9086 membrane-associated phosphatase noted above to be absent from ORT-UMN 88 is also not apparent in the H06030791 genome. These rearrangements, and several others examined, are nearly always bordered by transposons,

Table 3 Genome statistics of 0 . rhinotracheale strain ORT-UMN 88

\begin{tabular}{lrr}
\hline Attribute & \multicolumn{2}{c}{ Genome (total) } \\
\cline { 2 - 3 } & Value & \% of total $\mathbf{b}^{\mathbf{b}}$ \\
\hline Genome size (bp) & $2,397,867$ & $100.00 \%$ \\
DNA coding (bp) & $2,138,862$ & $89.20 \%$ \\
DNA G + C (bp) & 820,557 & $34.22 \%$ \\
Total genes ${ }^{\text {a }}$ & 2389 & $100.00 \%$ \\
Protein-coding genes & 2300 & $93.89 \%$ \\
RNA genes & 9 & $3.77 \%$ \\
rRNA operons & 3 & \\
tRNA genes & 43 & $1.80 \%$ \\
Pseudo genes & 36 & $1.60 \%$ \\
Genes with function prediction & 1337 & $59.61 \%$ \\
Genes assigned to COGs & 1374 & $61.26 \%$ \\
Genes assigned Pfam domains & 1494 & $66.61 \%$ \\
Genes with signal peptides & 270 & $12.04 \%$ \\
Genes with transmembrane helices & 500 & $22.29 \%$ \\
CRISPR repeats & 1 & \\
\hline
\end{tabular}

${ }^{a}$ Total genes include one noncoding RNA gene

${ }^{b}$ The total is based on either the size of the genome in base pairs or the total number of protein coding genes in the annotated genome.
Table 4 Number of genes associated with the $\mathbf{2 5}$ general COG functional categories of $O$. rhinotracheale strain ORT-UMN 88

\begin{tabular}{crrll}
\hline Code & Value & \% age & Description \\
\hline J & 133 & 5.57 & Translation, ribosomal structure and biogenesis \\
A & 0 & 0 & RNA processing and modification \\
K & 47 & 1.97 & Transcription \\
L & 116 & 4.86 & Replication, recombination and repair \\
B & 0 & 0 & Chromatin structure and dynamics \\
D & 20 & 0.84 & Cell cycle control, cell division, chromosome \\
& & & partitioning \\
Y & 0 & 0 & Nuclear structure \\
V & 34 & 1.42 & Defense mechanisms \\
T & 26 & 1.09 & Signal transduction mechanisms \\
M & 118 & 4.94 & Cell wall/membrane biogenesis \\
N & 3 & 0.13 & Cell motility \\
Z & 0 & 0 & Cytoskeleton \\
W & 0 & 0 & Extracellular structures \\
U & 29 & 1.21 & Intracellular trafficking and secretion \\
O & 66 & 2.76 & Posttranslational modification, protein turnover, \\
& & & chaperones \\
C & 74 & 3.1 & Energy production and conversion \\
G & 75 & 3.14 & Carbohydrate transport and metabolism \\
E & 109 & 4.56 & Amino acid transport and metabolism \\
F & 52 & 2.18 & Nucleotide transport and metabolism \\
H & 91 & 3.81 & Coenzyme transport and metabolism \\
I & 42 & 1.76 & Lipid transport and metabolism \\
P & 79 & 3.31 & Inorganic ion transport and metabolism \\
Q & 17 & 0.71 & Secondary metabolites biosynthesis, transport \\
R & 153 & 6.4 & General function prediction only \\
S & 90 & 3.77 & Function unknown \\
\hline
\end{tabular}

The total is based on the total number of protein coding genes in the annotated genome.

transposases or insertion sequences and are often accompanied by duplication of one or a few CDSs present at the points of sequence divergence. An additional prominent feature of the ORT-UMN 88 genome is an insertion of $\sim 47 \mathrm{~Kb}$ comprising 45 CDSs (locus tags Q785_1046510695), not present in either LMG 9086 or H06-030791, identified as an integrative and conjugative element using a web-based ICE resource [40]. ICEs are self-transmissible elements found in some Gram-positive and Gramnegative bacteria that often confer new phenotypes upon the recipient due to co-transfer of antibiotic resistance genes, virulence factors and other traits [41]. The ORTUMN 88 ICE contains the protypical integration/excision, conjugation and regulation modules as well as a tetracycline resistance element, a chemotaxis protein gene and a histidine kinase gene. Thus, it appears that multiple classes 


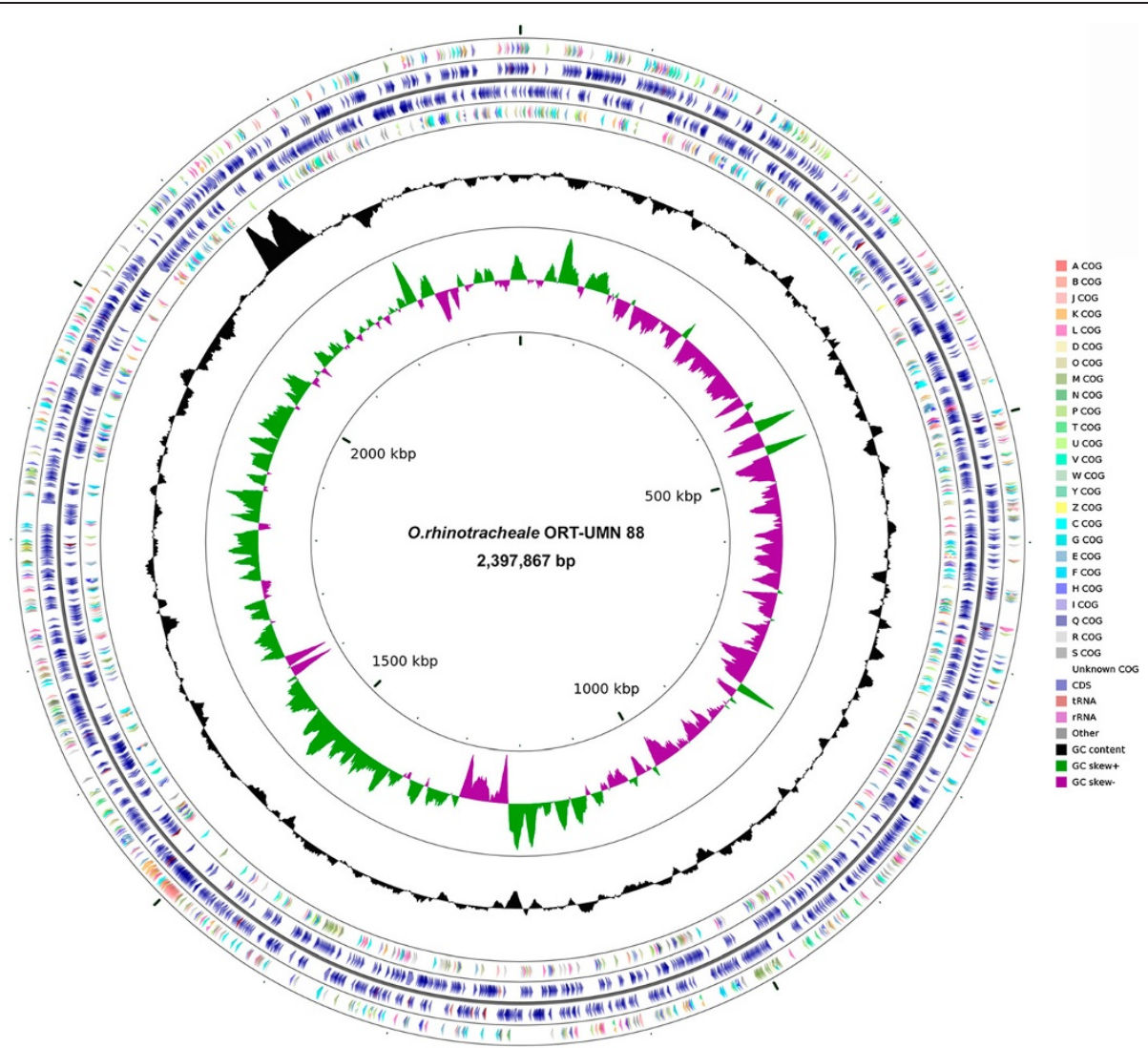

Figure 3 Graphical map of the O. rhinotracheale strain ORT-UMN 88 chromosome. From outside to the center: genes on forward strand (color by COG categories), CDS on forward strand, tRNA, rRNA, other; CDS on reverse strand, tRNA, rRNA, other, genes on reverse strand (color by COG categories); GC content; GC skew, where green indicates positive values and magenta indicates negative values.

of mobile elements likely play a role in shaping the genome structure and evolution of $O$. rhinotracheale.

While there are major organizational differences among the genomes of all three isolates, ORT-UMN 88 and H06-030791 share a higher degree of synteny with one another than either shares with LMG 9086. An additional feature shared exclusively between ORTUMN 88 and H06-030791 is a deletion in both of $\sim 37$ $\mathrm{Kb}$ found in LMG 9086, comprised primarily of CDSs annotated as hypothetical proteins but also including a holin family protein, an ATP-dependent serine protease, a helix-turn-helix protein and several phagerelated proteins. A number of CDSs in ORT-UMN 88 with obvious sequence divergence as compared to homologs in LMG 9086 are identical or nearly identical to homologs in H06-030791 [39]. These include several annotated as hypothetical proteins, an ROK family transcriptional regulator/sugar kinase, a Crp/Fnr family transcriptional regulator and the integral membrane protein and ferrous iron transporter FeoB. Both ORTUMN 88 and H06-030791 were isolated in the United States, in 1995 and 2006, respectively, while LMG 9086 was isolated in United Kingdom in 1994, suggesting that distinct clones of O. rhinotracheale may circulate in geographically distant locales.

ORT-UMN 88 is unique from the type strain with regard to its $\beta$-hemolytic phenotype when grown under appropriate conditions on blood agar [14]. A search of the ORT-UMN 88 genome for CDSs whose annotations suggest a function in hemolytic activity revealed only three candidates. Identical or nearly identical homologs were found in the LMG 9086 genome as well as in the genome of the $\beta$-hemolytic isolate H06-030791 [39]. An additional CDS annotated in LMG 9086 as a hemolysin was also found in both ORT-UMN 88 and H06-030791, with one and zero amino acid substitutions, respectively, relative to the type strain. Dependence on iron for growth in vitro is another phenotype known to be variable among the three $O$. rhinotracheale strains sequenced, with only H06-030791 capable of vigorous growth in the presence of an iron chelator [13]. Among 30 CDSs collectively found in all three genomes whose annotations suggest a role in iron acquisition or transport, all but FeoB are highly conserved among all isolates. As noted above, FeoB is predicted to be identical in ORT-UMN 88 and H06-030791 but unique in LMG 9086. All three isolates 
share 100\% amino acid identity over the N-terminal 395 amino acids but LMG 9086 has only $94.7 \%$ amino acid identity with ORT-UMN 88 and H06-030791 over the Cterminal 301 amino acids.

The genome sequence of ORT-UMN 88 reported here provides additional insights into the genetic structure and evolution of $O$. rhinotracheale. Additional analysis and experimentation is needed to understand the genetic basis of virulence in this bacterium but the availability of genome sequences from three genetically distinct isolates will greatly facilitate related efforts.

\section{Competing interests}

The authors declare that they have no competing interests.

\section{Authors' contributions}

EZ participated in genome sequencing and drafted the original manuscript. DB directed genome sequence assembly and bioinformatics analyses. WB participated in genome sequencing and post-sequencing analyses. LT conceived of the study and participated in genome sequencing. KR participated in post-sequencing analysis and revised the manuscript. All authors read and approved the final manuscript.

\section{Acknowledgements}

We thank Michael Baker of the lowa State University DNA Facility, Ames, IA and David Alt of the Infectious Bacterial Diseases Research Unit at the National Animal Disease Center, Ames, IA for their DNA sequencing expertise. We thank Linda Cox of the National Veterinary Services Laboratories in Ames, IA for performing the biochemical testing and Judith Stasko and James Fosse of the National Centers for Animal Health, Ames, IA for electron microscopy and image preparation for publication, respectively.

\section{Author details}

${ }^{1}$ Ruminant Diseases and Immunology Research Unit, U. S. Department of Agriculture, Agricultural Research Service, National Animal Disease Center, Ames, IA, USA. Infectious Bacterial Diseases Research Unit, U. S. Department of Agriculture, Agricultural Research Service, National Animal Disease Center, Ames, IA, USA. ${ }^{3}$ Roy J. Carver Department of Biochemistry, Biophysics and Molecular Biology, lowa State University, Ames, IA, USA

Received: 5 June 2014 Accepted: 29 October 2014 Published: 8 December 2014

\section{References}

1. Chin RP, Van Empel PCM, Hafez HM. Ornithobacterium rhinotracheale infection. In: Saif YM, editor. Diseases of Poultry. 12th ed. Ames, IA: Blackwell Publishing; 2008: p. 765-74

2. Charlton BR, Channing-Santiago SE, Bickford AA, Cardona CJ, Chin RP, Cooper GL, Droual R, Jeffrey JS, Meteyer CU, Shivaprasad HL, Walker RL. Preliminary characterization of a pleomorphic gram-negative rod associated with avian respiratory disease. J Vet Diagn Invest. 1993; 5:47-51. PMID: 8466980.

3. Vandamme P, Segers P, Vancanneyt M, Van Hove K, Mutters R, Hommez J, Dewhirst F, Paster B, Kersters K, Falsen E, Devriese LA, Bisgaard M, Hinz K-H, Mannheim W. Ornithobacterium rhinotracheale gen. nov. sp. nov., isolated from the avian respiratory tract. Int J System Bacteriol. 1994; 44(1):24-37. PMID: 8123560.

4. Hafez HM, Genus VP, XXXIX. Ornithobacterium Vandamme, Segers, Vancanneyt, Van Hove, Mutters, Hommez, Dewhirst, Paster, Kersters, Falsen, Devriese, Bisgaard, Hinz and Mannheim 1994b, 35 ${ }^{\mathrm{VP}}$. In: Krieg NR, Staley JT, Brown DR, Hedlund BP, Paster BJ, Ward NL, Ludwig W, Whitman WB, editors. Bergey's Manual of Systematic Bacteriology, Volume 4. 2nd ed. New York: Springer; 2011: p. 250-4.

5. Hafez HM, Lierz M. Ornithobacterium rhinotracheale in nestling falcons. Avian Dis. 2010; 54(1):161-3. PMID: 20408418.

6. van Veen L, Gruys E, Frik K, van Empel P. Increased condemnation of broilers associated with Ornithobacterium rhinotracheale. Vet Rec. 2000; 147(15):422-3. doi:10.1136/vr.147.15.422.
7. Sprenger SJ, Halvorson DA, Nagaraja KV, Spasojevic R, Dutton RS, Shaw DP. Ornithobacterium rhinotracheale infection in commercial laying-type chickens. Avian Dis. 2000; 44(3):725-9. PMID: 11007028

8. De Rosa M, Droual R, Chin RP, Shivaprasad HL, Walker RL. Ornithobacterium rhinotracheale infection in turkey breeders. Avian Dis. 1996; 40(4):865-74. doi:10.2307/1592311

9. van Empel PCM, Hafez HM. Ornithobacterium rhinotracheale: a review. Avian Pathol. 1999: 28(3):217-27. doi:10.1080/03079459994704.

10. Schuijffel DF, van Empel PCM, Segers RPAM, Van Putten JPM, Nuijten PJM. Vaccine potential of recombinant Ornithobacterium rhinotracheale antigens. Vaccine. 2006; 24:1858-67. doi:10.1016/j.vaccine.2005.10.031.

11. Roepke DC, Back A, Shaw DP, Nagaraja KV, Sprenger SJ, Halvorson DA. Isolation and identification of Ornithobacterium rhinotracheale from commercial turkey flocks in the Upper Midwest. Avian Dis. 1998; 42(1):219-21. PMID: 9533106

12. Sprenger SJ, Back A, Shaw DP, Nagaraja KV, Roepke DC, Halvorson DA. Ornithobacterium rhinotracheale infection in turkeys: experimental reproduction of the disease. Avian Dis. 1998; 42(1):154-61. PMID: 9533093.

13. Tabatabai LB, Zehr ES, Zimmerli MK, Nagaraja KV. Iron acquisition by Ornithobacterium rhinotracheale. Avian Dis. 2008; 52(3):419-25. PMID: 18939629

14. Tabatabai LB, Zimmerli MK, Zehr ES, Briggs RE, Tatum FM. Ornithobacterium rhinotracheale North American field isolates express a hemolysin-like protein. Avian Dis. 2010; 54(3):994-1001. PMID: 20945779.

15. Bernardet JF, Nakagawa Y, Holmes B. Proposed minimal standards for describing new taxa of the family Flavobacteriaceae, and emended description of the family. Int J Syst Evol Microbiol. 2002; 52:1049-70. doi:10.1099/ijs. 0.02136-0.

16. Tamura K, Peterson D, Peterson N, Stecher G, Nei M, Kumar S. MEGA5: Molecular evolutionary genetics analysis using maximum likelihood, evolutionary distance, and maximum parsimony methods. Mol Biol Evol. 2011; 28(10):2731-9. doi:10.1093/molbev/msr121.

17. Field D, Garrity G, Gray T, Morrison N, Selengut J, Sterk P, Tatusova T, Thomson N, Allen MJ, Angiuoli SV, Ashburner M, Axelrod N, Baldauf S, Ballard S, Boore J, Cochrane G, Cole J, Dawyndt P, De Vos P, dePamphilis C, Edwards R, Faruque N, Feldman R, Gilbert J, Gilna P, Glockner FO, Goldtein P, Guralnick R, Half D, Hancock D, et al. The minimum information about a genome sequence (MIGS) specification. Nat Biotechnol. 2008; 26(5):541-7. doi: 10.1038/nbt1360.

18. In: Garrity GM, Parker CT, editors. Nomenclature Abstract for "Bacteria". The NamesforLife Abstracts. NamesforLife, LLC; 2013. http://doi.org/10.1601/nm.419.

19. Woese CR, Kandler O, Wheelis ML. Towards a natural system of organisms: proposal for the domains Archaea, Bacteria, and Eucarya. Proc Natl Acad Sci U S A. 1990; 87:4576-9.

20. In: Garrity GM, Parker CT, editors. Nomenclature Abstract for "Bacteroidetes". The NamesforLife Abstracts. NamesforLife, LLC; 2013. http://doi.org/10.1601/nm.7927.

21. Garrity GM, Lilburn TG, Cole JR, Harrison SH, Euzéby J, Tindall BJ. Taxonomic outline of the Bacteria and Archaea, Release 7.7 March 6 Part 1 - The "Archea", Phyla "Crenarchaeota" and Euryarchaeota". Taxonomic Outline. 2007; 2007:551-73. doi: 10.1601/TOBA7.7.

22. In: Garrity GM, Parker CT, editors. Nomenclature Abstract for Flavobacteriia. The NamesforLife Abstracts. NamesforLife, LLC; 2014. http://doi.namesforlife. com/10.1601/nm.22978.

23. Bernardet J-F. Class II. Flavobacteriia class. nov. In: Krieg NR, Staley JT, Brown DR, Hedlund BP, Paster BJ, Ward NL, Ludwig W, Whitman WB, editors. Bergey's Manual of Systematic Bacteriology, Volume 4. 2nd ed. New York: Springer; 2011: p. 105.

24. In: Garrity GM, Parker CT, editors. Nomenclature Abstract for Flavobacteriales. The NamesforLife Abstracts. NamesforLife, LLC; 2012. http://doi.org/10.1601/nm.8069.

25. Bernardet J-F. Order I. Flavobacteriales ord. nov. In: Krieg NR, Staley JT, Brown DR, Hedlund BP, Paster BJ, Ward NL, Ludwig W, Whitman WB, editors. Bergey's Manual of Systematic Bacteriology. 2nd ed. New York: Springer; 2011: p. 105.

26. In: Garrity GM, Parker $C$, editors. Nomenclature Abstract for Flavobacteriaceae. The NamesforLife Abstracts. NamesforLife, LLC; 2014. http://doi.org/10.1601/nm.8070.

27. Reichenbach H. Order 1. Cytophagales Leadbetter 1974, 99AL. In: Holt JG, editor. Bergey's Manual of Systematic Bacteriology, Volume 3. 1st ed. Baltimore, MD: The Williams and Wilkins Co; 1989: p. 2011-3.

28. In: Garrity GM, Parker CT, editors. Nomenclature Abstract for Ornithobacterium. The NamesforLife Abstracts. NamesforLife, LLC; 2009. http://doi.org/10.1601/nm.8175.

29. Vandamme $P$, Segers $P$, Vancanneyt M, van Hove K, Mutters R, Hommez J, Dewhirst F, Paster B, Kersters K, Falsen E, Devriese LA, Bisgaard M, Hinz K-H, 
Mannheim W. Ornithobacterium rhinotracheale gen. nov., sp. nov., isolated from the avian respiratory tract. Int J Syst Bacteriol. 1994; 44:24-37. doi: 10.1099/00207713-44-1-24.

30. (BAuA) GFIfOSaH. 2010 Classification of prokaryotes (bacteria and archaea) into risk groups, technical rules for biological agents (TRBA) 466:159. Bundesanstalt für Arbeitsshutz und Arbeitsmedizin (BAuA). http://www.baua. de/de/Startseite.html.

31. Ashburner M, Ball CA, Blake JA, Botstein D, Butler H, Cherry JM, Davis AP, Dolinski K Dwight SS, Eppig J, Harris MA, Hill DP, Issel-Tarver L, Kasarskis A, Lewis S, Matese JC, Richardson JE, Ringwald M, Rubin GM, Sherlock G. Gene ontology: tool for the unification of biology. Nat Biotechnol. 2000; 25(1):25-9. doi: 10.1038/75556.

32. Chevreux B, Wetter T, Suhai $S$. Genome sequence assembly using trace signals and additional sequence information. Computer Science and Biology. Comp Sci Biol: Proc German Conference on Bioinformatics GCB '99. 1999; 99:45-56. http://www.bioinfo.de/isb/gcb99/talks/chevreux/.

33. Bonfield JK, Whitwham A. Gap5-editing the billion fragment sequence assemby. Bioinformatics. 2010; 26(14):1699-703. doi:10.1093/bioinformatics/ btq268.

34. Ronen R, Boucher C, Chitsaz H, Pevzner P. SEQuel: improving the accuracy of genome assemblies. Bioinformatics. 2012; 28(12):i188-96. doi:10.1093/ bioinformatics/bts219.

35. portal NWGSWgsp. https://submit.ncbi.nlm.nih.gov/subs/wgs/

36. Petersen TN, Brunak S, von Heijne G, Nielsen H. SignalP 4.0: discriminating signal peptides from transmembrane regions. Nat Methods. 2011; 8(10):785-6. doi:10.1038/nmeth.1701.

37. Krogh A, Larson B, von Heijne G, Sonnhammer ELL. Predicting transmembrane protein topology with a hidden Markov model: Application to complete genomes. J Mol Biol. 2001; 305(3):567-80. doi:10.1006/jmbi.2000.4315

38. Grissa I, Vergnaud G, Pourcel C. CRISPRFinder: a web tool to identify clustered regularly interspaced short palindromic repeats. Nucleic Acids Res. 2007; 35:W52-7. doi:10.1093/nar/gkm360.

39. Zehr ES, Bayles DO, Boatwright WD, Tabatabai LB, Register KB. Non-contiguous finished genome of Ornithobacterium rhinotracheale strain H06-030791. Stand Genomic Sci. 2014: 9:14. doi: 10.1186/1944-3277-10-14.

40. Bi D, Xu Z, Harrison EM, Tai C, Wei Y, He X, Jia S, Deng Z, Rajakumar K, Ou H-Y. ICEberg: a web-based resource for integrative and conjugative elements found in Bacteria. NAR. 2012; 40(D1):D621-6. doi:10/1093/nar/gkr846.

41. Wozniak RAF, Waldor MK. Integrative and conjugative elements: mosaic mobile genetic elements enabling dynamic lateral gene flow. Nat Rev Microbiol. 2010; 8(8):552-63. doi:10.1038/nrmicro2382.

doi:10.1186/1944-3277-9-16

Cite this article as: Zehr et al:: Complete genome sequence of

Ornithobacterium rhinotracheale strain ORT-UMN 88. Standards in Genomic Sciences 2014 9:16.

\section{Submit your next manuscript to BioMed Central and take full advantage of:}

- Convenient online submission

- Thorough peer review

- No space constraints or color figure charges

- Immediate publication on acceptance

- Inclusion in PubMed, CAS, Scopus and Google Scholar

- Research which is freely available for redistribution 